\title{
$\therefore$ Herbal Medicinal based Approach for Alzheimer Disease - A Mathematical Model
}

\section{Arora Komal', Khurana Pooja ${ }^{2}$, Kumar Deepak ${ }^{2}$}

'Department of Biotechnology, Faculty of Engineering and Technology, Manav Rachna International Institute of Research \& Studies, Faridabad, Haryana, India; 'Department of Applied Science, Faculty of Engineering and Technology, Manav Rachna International lnstitute of Research \& Studies, Faridabad, Haryana, India.

\section{ABSTRACT}

Introduction: Due to the cases of more than 1 million (in India) and more than 80 million (worldwide) of Alzheimer disease, there is an immediate need of finding a cure for Alzheimer. Alzheimer disease, a type of dementia, is a neurodegenerative, progressive disease that gives rise to troubles and issues related to cognitive functions. It is not a normal part of ageing; though the greatest known risk factor is increasing age.

Aim: Many treatments and many medications have been found but their efficacy to reach Blood-Brain Barrier and rate of betaamyloid clearance is very low. Moreover, drawbacks like cost, drug resistance and side effects bringing down their success rate.

Methodology: Considering the problem, this entry focuses on the alternate ways (herbal medicine) for Alzheimer cure by generalizing the mathematical model to investigate the effect of selected medicinal plants on the levels of amyloid-beta peptides, the characteristic hallmark of Alzheimer.

Results: We have analyzed the effect of active compounds of five potent medicinal plants at different dosages i.e. 250 mg/ day, $500 \mathrm{mg} /$ day, $750 \mathrm{mg} /$ day and $1000 \mathrm{mg} /$ day concerning time and found Withania somnifera as the best plant amongst five as it showed an effective decline in the beta-amyloid levels at $500 \mathrm{mg} / \mathrm{day}$. We have also examined the ADME ( Absorption, Distribution, Metabolism and Excretion) profile of the selected plants using the Swiss ADME server that revealed no violation of Lipinski's rule.

Conclusion: This model can act as a utility model for formulating herbal-based compounds that increase the rate of amyloidbeta clearance from the brain by inhibiting aggregation of amyloid-beta with least/no side effects.

Key Words: Alzheimer disease, Amyloid-beta, Mathematical model, Herbal approach, Medicinal plant, Dosage

\section{INTRODUCTION}

The brain, the central part of our body, controller of all the activities, is made of 100 billion nerves. All the nerves have their specialized functions to perform. Some are involved in thinking, behaviour and memory while others are involved in hearing, audition, gustation, vision and other activities forming a communicating network between different cells. Nerves that are involved in cognitive activities, when starts degenerating lead to the loss of memory. Deteriorative association between the brain cells which decrease the acetylcholine neurotransmitter is the main cause of memory loss, leads to dementia. ${ }^{1}$ Synapses (the connection between the different neurons), a major expressway or a site of communication for memories, emotions, sensations, thoughts and movements permit information to pass via chemical pulses between different neurons.

Alzheimer's disease (AD) is a neurodegenerative, inevitable, progressive disorder that affects memory, thinking behaviour and other potential activities. ${ }^{2}$ Worldwide, more than 25 million people are suffering from dementia, which more of them are from AD. It has been estimated that approximately about 5 million fresh/ new cases happening each year and this figure is expected to become two-fold after every two decades ( 20 years).

The underlying and foremost step of the disease is to strike the brain's memory centre leading to the individuals of AD being more forgetful and distracted. The initial stage of AD is difficult to be diagnosed as its symptoms are noticeable usually at

\section{Corresponding Author:}

Kumar Deepak, Department of Applied Science, Faculty of Engineering and Technology, Manav Rachna International Institute of Research \& Studies, Faridabad, Haryana, India; Email: deepakman12@gmail.com

ISSN: 2231-2196 (Print)

Received: 17.02 .2021
ISSN: 0975-5241 (Online)

Revised: 21.04 .2021
Accepted: 06.06.2021
Published: 09.11 .2021 
an advanced stage. The sequential cleavage of APP (Amyloid Precursor protein), results in the formation of peptide Amyloid-beta by beta-secretase followed by gamma-secretase. This is known as the Amyloidogenic pathway. The enzyme alpha-secretase competes with gamma-secretase to stop this amyloidogenic pathway. Competition of alpha-secretase with gamma-secretase is the non-amyloidogenic pathway., According to the amyloid cascade hypothesis, imbalances between the formation and removal of amyloid beta results in the dysfunction of neurons and ultimately cell death. Different forms of amyloid-beta in terms of structure can occur such as oligomeric, proto fibrillar, and fibrils. ${ }^{5}$ Accumulation of deposits of beta-amyloid protein outside nerve cells results in the formation of hard plaque. Simultaneously, the accumulation of malformed versions of tau proteins inside the neurons results in the collapsing of neuron's transport microtubules. ${ }^{6}$ As time passes, the functioning of neurons become less efficient or die, ultimately fail to communicate with one another causing the shrinkage of brain tissue. One's judgment becomes awful as the disease spreads to the outer layer of the brain. Age and genetic factors are the known risks associated with Alzheimer. Other factors such as gender, awareness, previous head injury, family history, exposure to heavy metals, down's syndrome contribute greatly to the development of AD. Individuals having down's syndrome, after 40 years of age, develop almost the same neuropathological symptoms of $\mathrm{AD}$ and thus the strong evidence for the genetic premise of Alzheimer disorder. ${ }^{7} 2-3 \%$ of early-onset AD cases are associated with the mutation caused on chromosome number 21 (the chromosome that encodes the amyloid-beta peptide precursor i.e. APP) whereas $70-80 \%$ of AD cases (early onset) are associated with the mutations in presenilin 1 (PS1) gene present on chromosome number 14 and $20-25 \%$ of the early cases are linked to the mutations in presenilin 2 (PS2) present on chromosome number 1. APP, PS1 and PS2 alter the processing mechanism of APP that leads to increased amyloid-beta production. APP cleavage by enzyme beta-secretase followed by cleavage by gamma-secretase results in the formation of amyloid-beta. Deposition of these amyloid-beta peptides is a first step in the aetiology and pathogenesis of Alzheimer disease followed by other characteristics of AD such as microtubule misfolding (neurofibrillary tangles), loss of synaptic connection, and dementia. Apo E gene encoded on chromosome number 19 increases the $50 \%$ risk of developing Alzheimer.

According to the computed value, it has been reported that around 5.4 million Americans are suffering from Alzheimer dementia in 2017 in which 5.3 million are having late-onset Alzheimer (65 years of age or more). It ranks fifth in terms of causing death. ${ }^{8}$

The main cause of Alzheimer is the deterioration and death of neurons that are responsible for thinking, learning and behaviour and as the neurons degenerate it affects the entire brain. It is differentiated from the normal brain as the ac- cumulation of deposits of beta-amyloid plaques and neurofibrillary tangles causes shrinkage of the brain. ${ }^{9}$

There is a conformational change in the soluble beta monomers to form the beta-sheet rich misfolded structure and hence aggregates to form amyloid fibrils. Deposition of these fibrils outside the neurons, called senile plaques lead to neurodegeneration. ${ }^{9}$ Amyloid beta, a short peptide cleaved by enzymes $\beta$ (beta) secretase and $\gamma$ (gamma) secretase, is derived from the amyloid precursor protein (APP), a gene which is found on chromosome number $21 \mathrm{q} 21 .{ }^{10}$ Around 40 and 42 peptides of amino acids (beta-amyloid 40 and betaamyloid 42) are obtained by cleavage by $\beta$ secretase and then $\gamma$ secretase.

Tau, a protein associated with microtubules found in cell bodies and mainly in the axons of nerve cells in the CNS. Around 6 isoforms of human tau protein have been expressed by the phenomenon of alternate mRNA splicing from a single gene that contains 16 exons and is present on chromosome $17 \mathrm{q} 21$. Twisted fibres of the protein tau, called neurofibrillary tangles (intracytoplasmic structures) build up inside cells because collapsing of neuron's transport microtubules. ${ }^{11}$

Also, a decrease in the levels of acetylcholine due to its breakdown by an enzyme called acetylcholinesterase results in memory loss and hence Alzheimer.

Thus, amyloid accumulation, microtubules misfolding, dysfunction of cholinergic mechanism, oxidative stresses are some of the factors involved in the pathophysiology of Alzheimer disease. ${ }^{10}$

The distinguishing features of the brain describing the characteristic change that arises due to AD usually happen around 20 years before the emergence of symptoms and therapeutic remedy can be identified and accomplished. The phase where the slightest or suggestive symptoms appears offers a likely possibility for curative intercession that can decelerate the progression of the disease. There are four stages in the progression of dementia (starting from cognitively normal to dementia). The stage Mild cognitive impairment (MCI) appears before $\mathrm{AD}$ and for the early detection of Alzheimer, the transformation of stage MCI to stage $\mathrm{AD}$ is of agreeable concern. Assessment of significant biomarkers can be overriding to early (preclinical) diagnosing, monitoring, treating, and continuing phases of $\mathrm{AD}$ analysis. ${ }^{11}$ However, there is a requirement for standardizing such biomarkers for accurate and early diagnose of AD. This includes amyloid-beta, tat and phosphorylated tau, glucose, Positron emission tomography (PET), Cerebrospinal fluid (CSF), Apo E and telomere length, Magnetic Resonance Imaging (MRI), RNA interference. ${ }^{12-17}$ 


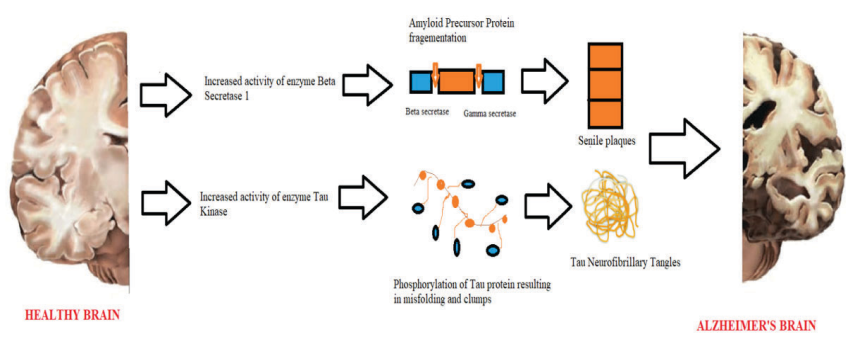

Figure 1: Mechanism of degeneration.

Food and drugs administration (FDA) approved drugs to treat symptoms related to Alzheimer's disease, that includes the class of drugs called "cholinesterase inhibitors". The cholinesterase inhibitors halt the process of disintegration and breakdown of a chemical messenger in the brain that is important for learning and memory. Examples of such drugs are donepezil, galantamine and rivastigmine approved for the treatment of mild to moderate Alzheimer disease. Other classes of drugs include $\mathrm{M}$ drugs (Memantine, melatonin, minocycline, modafinil). Memantine is an uncompetitive NMDA (N-methyl-d-aspartic acid receptor antagonist) and is approved for the management of moderate-to-severe $\mathrm{AD}$, Melatonin is a neuroprotector and antioxidant and anti-inflammatory in nature, Minocycline reduces neuroinflammation and CNS pathology and prevents cell death and Modafinil is a wake-promoting agent is approved for use in narcolepsy and obstructive sleep apnea. It improves global mental status, hippocampal neurogenesis, attention, and cognition. Amyloid-beta degrading enzymes such as an insulin-degrading enzyme, neprilysin, endothelin-converting enzyme decrease the levels of amyloid-beta is also one of the medications approved for Alzheimer treatment. ${ }^{18}$

Though numerous treatments and medications such as acetylcholinesterase inhibitors, M-drugs, amyloid degrading enzymes are already on the market, their results not indicating the complete clearance of amyloid-beta from the brain. Moreover, some of the downsides of these medications like toxicity, drug resistance, side effects, and cost urge the need to have a transition from these chemical medications towards the natural traditional medications in a form of herbal treatment. Plants are utilized as an essential source for various drugs in Indian medicinal history. The complete description of all the curative properties of the medicinal plants has been listed in Rigveda. After a while, various synthetic drugs developed and commenced which due to their drawbacks failed. Recently, the trend of using plants is again rising and is being utilized confidently.

Medicinal plants such as Curcuma longa, Withania somnifera, Bacopa monnieri, Centella Asiatica, Convolvulus pluricaulis have been reviewed, researched and documented to show potent responses in Alzheimer cure. These plants consist of active compounds like tannins, lignans, triterpenes, alkaloids, flavonoids, sterols and polyphenols and work by inhibiting fibrillation, relaxing CNS, promoting memory. ${ }^{19,20}$

\section{Table 1: Potential abilities of medicinal plants against Alzheimer disorder}

\begin{tabular}{|c|c|c|c|c|}
\hline $\begin{array}{l}\text { Plant's botanical } \\
\text { name (Common } \\
\text { name) }\end{array}$ & Family & Active constituents & Potential abilities & References \\
\hline $\begin{array}{l}\text { Curcuma longa } \\
\text { (Turmeric) }\end{array}$ & Zingiberaceae & Curcumin, turmerone oil & $\begin{array}{l}\text { Decrease amyloid-beta deposition and } \\
\text { levels, minimize oxidative stress, reduced } \\
\text { pro-inflammatory levels of cytokine }\end{array}$ & 21,22 \\
\hline $\begin{array}{l}\text { Bacopa monnieri } \\
\text { (Brahmi) }\end{array}$ & Plantaginaceae & $\begin{array}{l}\text { Triterpenoid bacosaponins, } \\
\text { alkaloids, plant sterols, } \\
\text { betulin acid, polyphenols, } \\
\text { and sulfhydryl compounds }\end{array}$ & $\begin{array}{l}\text { Improvisation of memory and cognitive ac- } \\
\text { tivities; promote Neotropic actions; inhibit } \\
\text { degeneration of acetylcholine; reversed the } \\
\text { functions like reduced choline acetyltrans- } \\
\text { ferase activity, lowers oxidative stress }\end{array}$ & 23,24 \\
\hline $\begin{array}{l}\text { Withania somnifera } \\
\text { (Ashwagandha) }\end{array}$ & Solanaceae & $\begin{array}{l}\text { Ergostane-type steroidal } \\
\text { lactones, phytosterols si- } \\
\text { toindosides, beta-sitoster- } \\
\text { ol, alkaloids, amino acids, } \\
\text { iron, withanolides }\end{array}$ & $\begin{array}{l}\text { Inhibits cell death caused by amyloid-beta } \\
\text { aggregation; prevents the formation of } \\
\text { fibrils; enhances cognitive functions like } \\
\text { memory and learning; increase acetylcho- } \\
\text { line and choline acetyltransferase activity; } \\
\text { regenerate axons and dendrites; }\end{array}$ & 25,26 \\
\hline $\begin{array}{l}\text { Centella asiatica } \\
\text { (Gotu kola) }\end{array}$ & Apiaceae & $\begin{array}{l}\text { Asiatic acid and asiatico- } \\
\text { side }\end{array}$ & $\begin{array}{l}\text { Enhances memory and intelligence; inhibit } \\
\text { beta-amyloid cell death; modulate oxidative } \\
\text { stress }\end{array}$ & $27,28,29$ \\
\hline $\begin{array}{l}\text { Convolvulus pluricau- } \\
\text { lis (Shankhpushpi) }\end{array}$ & Convolvulaceae & $\begin{array}{l}\text { Steroids, anthocyanins, } \\
\text { triterpenoids, glycosides, } \\
\text { flavanol }\end{array}$ & $\begin{array}{l}\text { Improves memory and cognitive func- } \\
\text { tions; enhance nootropic actions; calms } \\
\text { the nerves; enhance acetylcholine content; } \\
\text { increase functional growth of neurons }\end{array}$ & 30,31 \\
\hline
\end{tabular}




\section{MATERIAL AND METHODS}

\section{Mathematical model}

Alzheimer, a neurodegenerative disorder, affects the thinking, memory, behaviour and other activities of an individual. In addition to the effect on an individual's memory, it produces a considerable stretch to the society also and hence several medications like cholinesterase inhibitors, M drugs, NMDA antagonist, antioxidants, statins, PPAR gamma antagonist and some combinational approaches of these drugs were developed for the treatment of Alzheimer but despite all these treatments, condition of Alzheimer's patients and hence its influence on society is not improved. Herbal therapy is an alternative for the drugs available in the market that failed due to their drawbacks.

Various mathematical models have been made representing the role of amyloid-beta aggregation, tau phosphorylation, microglia's, astrocytes, macrophages, in the development and management of Alzheimer disease. ${ }^{32}$ Puri and Li describe the pathogenesis of Alzheimer in the form of a mathematical model..$^{33}$ Also, the mathematical model symbolizing the death of neurons in Alzheimer has also been constructed. ${ }^{34}$

This mathematical model acts as a template to determine the dosage of active constituents of medicinal plants in lowering the levels of amyloid-beta in the brain and helps in their clearance.

The extracellular amyloid beta-peptide satisfies the following equation:

$\frac{d A^{0}{ }_{\beta}}{d t}=\lambda_{N} \frac{N}{N_{0}}+\lambda_{A} \frac{A}{A_{0}}+\lambda_{D} \frac{D}{D_{0}}-\left(d_{A^{0} \beta}(M)+d_{A^{0} \beta D E}(D E)\right)+\frac{A_{\beta}^{0}}{A_{\beta}^{0}+k A_{\beta}^{0}}(1)$

To investigate the effective dosage of medicinal plants to clear the amyloid-beta levels from the brain, extract of five plants have been analyzed in four different doses $(250 \mathrm{mg} /$ day, $500 \mathrm{mg} /$ day, $750 \mathrm{mg} /$ day and $1000 \mathrm{mg} /$ day) for about 5 months.

The dosage equation is as follows:

$\frac{d A_{\beta}^{0}}{d t}=\lambda_{N} \frac{N}{N_{0}}+\lambda_{A} \frac{A}{A_{0}}+\lambda_{D} \frac{D}{D_{0}}-\left(d_{A^{0} \beta}(M)+d_{A^{0} \beta} D E(D E)\right)+\frac{H A_{\beta}^{0}}{A_{\beta}^{0}+k A_{\beta}^{0}}$

Initial value of $A^{0}{ }_{\beta}=92$

Parametric description

$\lambda_{N} \frac{N}{N_{0}}$ : Proteolytic degradation of APP by beta and gammasecretase releasing Amyloid beta.

$\lambda_{A} \frac{A}{A_{0}}$ : Release of amyloid-beta by activated astrocytes.

$A_{0}$ : Reference density of the astrocyte cells in the brain.

$\lambda_{D} \frac{D}{D_{0}}$ : Release of amyloid-beta by dendritic cells.

$D_{0}$ : Reference density of the dendritic cells in the brain.
$d_{A^{0}{ }_{\beta} M}(M)$ : Clearance of amyloid-beta by microglia.

$d_{A^{0}{ }_{\beta} D E}(D E)$ : Clearance of amyloid-beta by amyloid-beta degrading enzymes.

\section{$H$ : Dosage quantity}

$k$ :Michael's-Menten coefficient

\section{General solution of first-order differential equations-Euler's Method}

The general case for the solution of a first-order differential equation can be computed numerically approximations. The differential equation $\frac{d A^{0}{ }_{\beta}}{d t}=f\left(A_{\beta}^{0}, t\right)$ is replaced with the following approximation $\frac{A_{\beta}^{0}{ }_{\beta}\left(t_{0}+\Delta t\right)-A^{0}{ }_{\beta}\left(t_{0}\right)}{\Delta t}=f\left(t_{0}, A^{0}{ }_{\beta}\left(t_{0}\right)\right)$

For sufficiently small $\Delta t$. This can be arranged to

$$
A_{\beta}^{0}\left(t_{0}+\Delta t\right)=A_{\beta}^{0}\left(t_{0}\right)+\Delta t f\left(t_{0}, A^{0}{ }_{\beta}\left(t_{0}\right)\right)
$$

So that given step size $\Delta t$ and initial condition $A^{0}{ }_{\beta}\left(t_{0}\right)$.

\section{ADME (Absorption, Distribution, Metabolism, Excretion) Profile analysis}

The exploration of pharmacokinetics and physio-chemical characterization is an important step in the identification of any drug to cure the disease effectively. Here, we have used the swiss ADME server to investigate the drug-likeness properties of the plants selected for reducing the amyloidbeta concentration from the brain [35]. Various parameters like molecular weight, lipophilicity, water-solubility, gastrointestinal absorption, CYP inhibitors, bioavailability score have been calculated using swiss ADME and listed in table 2. Also, the violations of Lipinski's rule (if any) have been reported.

\section{RESULTS AND DISCUSSIONS}

Amyloid beta forms in the brain of every individual by the cleavage of APP by the action of enzyme beta-secretase followed by gamma-secretase. However, it excretes out of the brain, meaning the production and removal of amyloid-beta is a simultaneous process. The imbalances between the formation and removal of amyloid-beta from the brain lead to its accumulation.

The alternative for synthetic drugs is herbal medicine. Medicinal plants due to the presence of active constituents have potential in the treatment of various disorders. Active constituents such as curcumin, steroids, glycosides, anthocyanins, terpenoids, Asiatic acid, alkaloids have been reported and documented for the potent purpose of reducing beta-amyloid levels. To find an effective cure, it is very important to explore pharmacokinetics and physicochemical properties such 
as water solubility, gastrointestinal absorption, lipophilicity, bioavailability score and many more. The Lipinski's rule is a standardized rule for drug development that determines the drug-likeness properties of a molecule and according to the rule drug molecule having MW $>500 \mathrm{~g} / \mathrm{mol}$, hydrogen-bonddonating atoms $>5$, Hydrogen-bond-accepting atoms $>10$, or $\log \mathrm{p}>5$ is not considered as a good pharmaceutical agent in terms of oral activity. The natural molecules we have selected for the cure of Alzheimer showed good pharmacokinetics and Physico-chemical properties and no violation of Lipinski's rule except for active compounds bacoside and asiaticoside present in Bacopa monniera and Centella Asiatica. In addition to this, the dosage of different plants has also been investigated at $250 \mathrm{mg} /$ day, $500 \mathrm{mg} /$ day, $750 \mathrm{mg} /$ day and $1000 \mathrm{mg} /$ day for five months where Curcuma longa showed the best results at $1000 \mathrm{mg} /$ day dose, Bacapo monnieri at $750 \mathrm{mg} / \mathrm{day}$, Convolvulus pluricaulis at $1000 \mathrm{mg} /$ day dose, Withania somnifera at $500 \mathrm{mg} /$ day, and Centella Asiatica at $750 \mathrm{mg} /$ day; the results of which are interpreted well in the graphs viz Figure 2, 3, 4, 5, and 6. Our inference from the results implies that Withania somnifera is the best amongst five plants as it is effective in clearing amyloid-beta at a lower dose i.e., $500 \mathrm{mg}$ /day as compared to others.

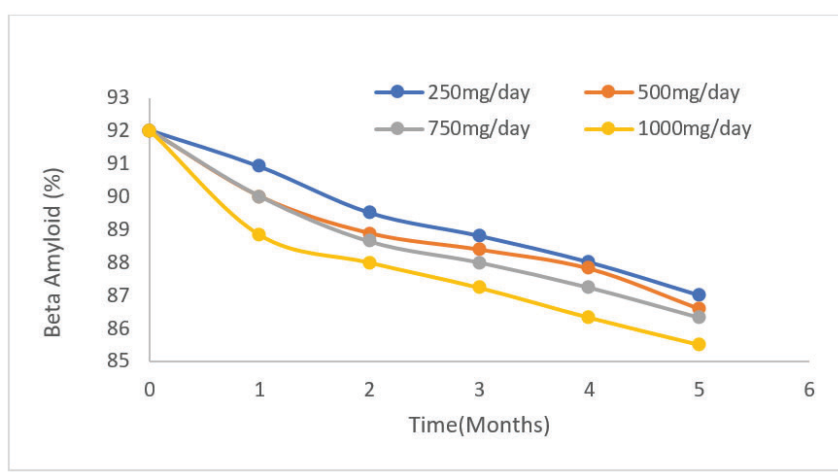

Figure 2: Effect of curcumin on the levels of amyloid-beta concerning the time at different dosages.

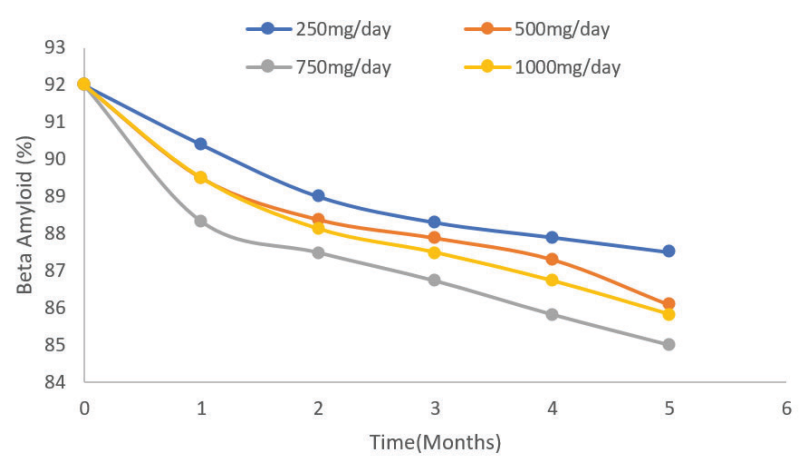

Figure 3: Effect of bacoside on the levels of amyloid-beta concerning the time at different dosages.

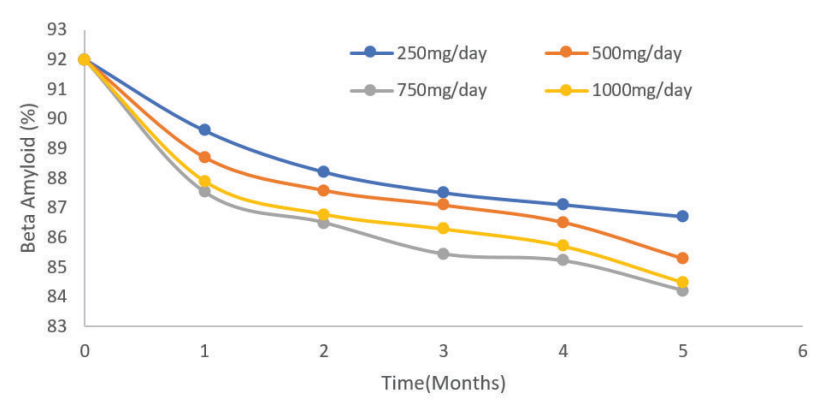

Figure 4: Effect of asiaticoside on the levels of amyloid-beta concerning the time at different dosages.

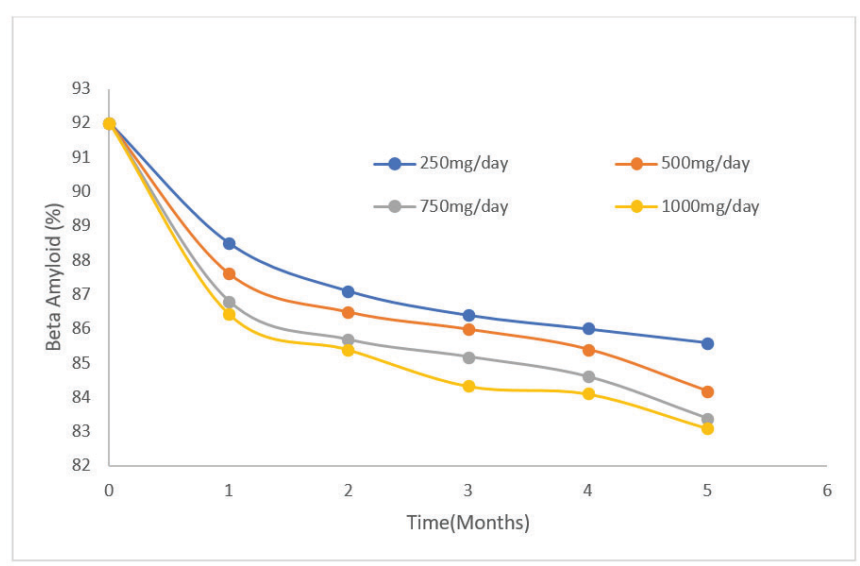

Figure 5: Effect of convolvine on the levels of amyloid-beta concerning the time at different dosages.

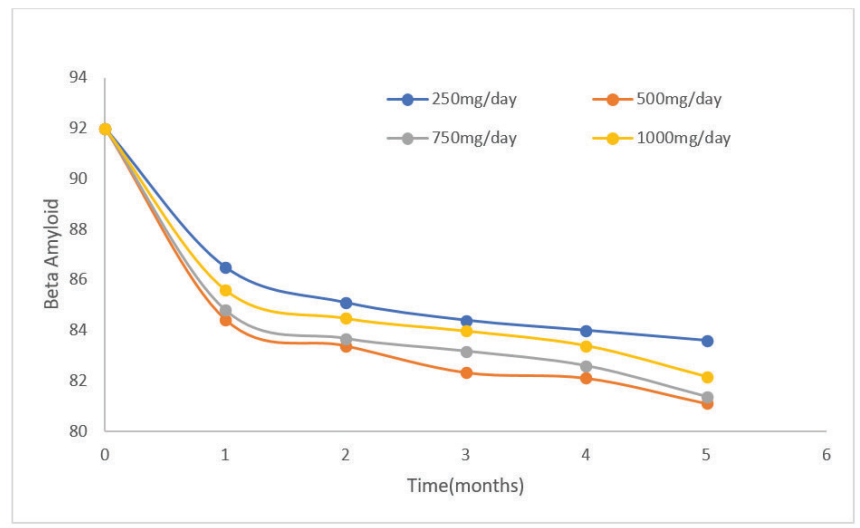

Figure 6: Effect of withaferin Aon on the levels of amyloid-beta concerning the time at different dosages.

Figure 2 to 6 represents the levels of Beta Amyliod and different doses with curcumin, bacoside, asiaticoside, convolvine and withaferin respectively. 
Table 2: Physico-chemical and pharmacokinetic characterization of active compounds of selected natural plants.

\begin{tabular}{|c|c|c|c|c|c|c|}
\hline \multicolumn{2}{|l|}{ Parameters } & Curcumin & Withaferin A & Bacoside & Asiaticoside & Convolvine \\
\hline \multicolumn{2}{|c|}{$\begin{array}{l}\text { Formula } \\
\text { Molecular weight }(\mathrm{g} / \mathrm{mol})\end{array}$} & $\begin{array}{l}\mathrm{C}_{21} \mathrm{H}_{20} \mathrm{O}_{6} \\
68.38\end{array}$ & $\begin{array}{l}\mathrm{C}_{28} \mathrm{H}_{38} \mathrm{O}_{6} \\
470.60\end{array}$ & $\begin{array}{l}\mathrm{C}_{41} \mathrm{H}_{68} \mathrm{O}_{13} \\
768.97\end{array}$ & $\begin{array}{l}\mathrm{C}_{48} \mathrm{H}_{78} \mathrm{O}_{19} \\
959.12\end{array}$ & $\begin{array}{l}\mathrm{C}_{16} \mathrm{H}_{21} \mathrm{NO}_{4} \\
291.34\end{array}$ \\
\hline $\begin{array}{l}\text { Water solu- } \\
\text { bility }\end{array}$ & $\begin{array}{l}\text { Log S } \\
\text { Solubility } \\
\text { Class }\end{array}$ & $\begin{array}{l}-3.94 \\
4.22 \mathrm{e}-02 \mathrm{mg} / \mathrm{ml} \\
\text { Soluble }\end{array}$ & $\begin{array}{l}-4.97 \\
5.01 e-03 \mathrm{mg} / \mathrm{ml} \\
\text { Moderately soluble }\end{array}$ & $\begin{array}{l}-5.69 \\
1.58 \mathrm{e}-03 \mathrm{mg} / \mathrm{ml} \\
\text { Moderately } \\
\text { soluble }\end{array}$ & $\begin{array}{l}-5.19 \\
6.20 e-03 \mathrm{mg} / \mathrm{ml} \\
\text { Moderately } \\
\text { soluble }\end{array}$ & $\begin{array}{l}-3.22 \\
1.77 \mathrm{e}-01 \mathrm{mg} / \mathrm{ml} \\
\text { Soluble }\end{array}$ \\
\hline \multicolumn{2}{|c|}{ Gastrointestinal absorption } & High & High & Low & Low & High \\
\hline \multicolumn{2}{|c|}{ p-glycoprotein substrate } & No & Yes & Yes & Yes & No \\
\hline \multicolumn{2}{|c|}{ Lipophilicity (Log Po/w) } & 3.27 & 3.39 & 4.96 & 2.50 & 3.32 \\
\hline \multicolumn{2}{|c|}{ CYPıA2 inhibitor } & No & No & No & No & No \\
\hline \multicolumn{2}{|c|}{$\mathrm{CYP}_{2} \mathrm{C}_{19}$ inhibitor } & No & No & No & No & No \\
\hline \multicolumn{2}{|c|}{$\mathrm{CYP}_{2} \mathrm{C}_{9}$ inhibitor } & Yes & No & No & No & No \\
\hline \multicolumn{2}{|c|}{ CYP2D6 inhibitor } & No & No & No & No & Yes \\
\hline \multicolumn{2}{|c|}{$\mathrm{CYP}_{3} \mathrm{~A}_{4}$ inhibitor } & No & No & No & No & No \\
\hline \multicolumn{2}{|c|}{ Bioavailability score } & 0.55 & 0.55 & 0.17 & 0.17 & 0.55 \\
\hline \multicolumn{2}{|c|}{$\begin{array}{l}\text { Any violation of Lipinski's } \\
\text { rule }\end{array}$} & No & No & $\begin{array}{l}\text { Yes ( } 3 \text { viola- } \\
\text { tions) } \\
\mathrm{MW}>500, \mathrm{~N} \text { or } \\
\mathrm{O}>10, \mathrm{NH} \text { or } \\
\mathrm{OH}>5\end{array}$ & $\begin{array}{l}\text { Yes (3 violations) } \\
\mathrm{MW}>500, \mathrm{~N} \text { or } \\
\mathrm{O}>1 \mathrm{O}, \mathrm{NH} \text { or } \\
\mathrm{OH}>5\end{array}$ & No \\
\hline
\end{tabular}

\section{CONCLUSION}

Due to the challenges faced by the pharmaceutical industries, the treatment of neurodegenerative diseases is becoming expensive, inefficient and riskier. This caused a transition from these chemical medications towards the natural traditional medications in a form of herbal treatment. Considering the effects of memory, thinking and other essential activities on Alzheimer's patients and its stress to society, this research involves the formation of the mathematical model that acts as a template to represent the change in the levels of beta-amyloid protein (the defining feature of Alzheimer disease) upon intake of herbal formulation in form of active constituents present in the medicinal plant. The potential ability of plants in inhibiting fibrillation and hence reducing the amyloid-beta levels is due to the presence of active constituents like tannins, lignans, triterpenes, alkaloids, flavonoids, sterols and polyphenols. For different doses, the active component of the selected plant was analyzed where information from the graph reveals that all selected plants showed reduced amyloid beta levels, however, Withania somnifera showed the best results at a lower dose $(50 \mathrm{mg} /$ day) concerning time as compared to others. Also, the results of ADME analysis showed good bioavailability score, solubility, lipophilicity

\section{ACKNOWLEDGEMENT}

The authors thank the Dept. of Biotechnology, MRIIRS LAB to provide data sets on lifestyle disorders to provide facts that motivate authors to do research work.

Conflict of interests: The authors declare no conflict of interest, financial or otherwise.

\section{Funding Agency: None}

\section{Contribution of Individual Authors}

Arora K. developed the theoretical formalism, performed the analytic calculations and performed the numerical simulations. Both Khurana P. and Kumar D. authors contributed to the final version of the manuscript.

\section{REFERENCES}

1. Talita H. Ferreira-Vieira, Isabella M. Guimaraes, Flavia R. Silva, and Fabiola M. Ribeiro . Alzheimer's Disease: Targeting the Cholinergic System. Curr Neuropharmacol. 2016 Jan; 14(1): 101-115. doi: 10.2174/1570159X13666150716165726

2. Mark W. Bondi, Emily C. Edmonds, David P. Salmon. Alzheimer's Disease: Past, Present, and Future. J Int Neuropsychol Soc. 2017 Oct; 23(9-10): 818-831. doi: 10.1017/ S135561771700100X

3. Dawkins, E. Small, D.H. Insights into the physiological function of the $\beta$-amyloid precursor protein: beyond Alzheimer's disease. 
J. Neurochem. 2014, 129, 756-769. https://doi.org/10.1111/ jnc. 12675

4. Zhang, Z. Song, M. Liu, X. Su Kang, S. Duong, D.M. Seyfried, N.T. Cao, X.; Cheng, L. Sun, Y.E. Ping Yu, S. et al. Deltasecretase cleaves amyloid precursor protein and regulates the pathogenesis in Alzheimer's disease. Nat. Commun. 2015, 6, 8762. doi: 10.1038/ncomms9762.

5. Macchi B, Marino-Merlo F, Frezza C, Cuzzocrea S, Mastino A. Inflammation and programmed cell death in Alzheimer's disease: comparison of the central nervous system and peripheral blood. Mol Neurobiol., 2014;50:463-72. DOI: 10.1007/s12035014-8641-9

6. Boutajangout A, Wisniewski T. Tau-based therapeutic approaches for Alzheimer's disease - a mini-review. Gerontology. 2014; 60:381-385. https://doi.org/10.1159/000358875

7. Filley CM. Alzheimer's disease in women. Am J Obstet Gynecol. 1997;176:1-7. doi: 10.1016/s0002-9378(97)80003-8.

8. 2020 Alzheimer's disease facts and figures. [ALZHEIMER'S ASSOCIATION REPORT]. Alzheimer's Association: 10 March $2020 \mathrm{https}: / /$ doi.org/10.1002/alz.12068

9. Liu Z, Zhang A, Sun H. Two decades of new drug discovery and development for Alzheimer's disease. RSC Adv. 2017;7(10):6046-6058. DOI: 10.1039/C6RA26737H.

10. Thakur AK, Kamboj P, Goswami K. Pathophysiology and management of Alzheimer's disease: an overview. J Anal Pharm Res. 2018;9(2):226-235. DOI: 10.15406/japlr.2018.07.00230.

11. Thies, W. Bleiler, L. Alzheimer's Association Report: 2013 Alzheimer's Disease Facts and Figures. Alzheimer Dement.2013, 9, 208-245.

12. Schaffer C, Sarad N, DeCrumpe A, Goswami D, Herrmann S, Morales J, Patel P, Osborne J. Biomarkers in the Diagnosis and Prognosis of Alzheimer's Disease. J Lab Autom. 2015, 2014 Society for Laboratory Automation and Screening. doi: $10.1177 / 2211068214559979$.

13. Scheuner A, D Eckman, Jensen C, Secreted Amyloid Beta-Protein Similar to That in the Senile Plaques of Alzheimer's Disease Is Increased In Vivo by the Presenilin 1 and 2 and APP Mutations Linked to Familial Alzheimer's Disease. Nat. Med. 1996, 2, 864-870. DOI: 10.1038/nm0896-864

14. Jesus A, Jose J L, Mar P, Felix H. Role of tau protein in both physiological and pathological conditions. Physiol Rev. 2004 Apr;84(2):361-84. doi: 10.1152/physrev.00024.2003.

15. Shah, K. DeSilva, S. Abbruscato, T. The Role of Glucose Transporters in Brain Disease: Diabetes and Alzheimer's Disease. Int J Mol Sci. 2012, 13, 12629-12655. doi: 10.3390/ijms131012629.

16. Patel, S. Shah, R. J. Coleman, P. Potential Peripheral Biomarkers for the Diagnosis of Alzheimer's disease. Int J Alzheimer's Dis. 2011; 2(11):1-9. doi: 10.4061/2011/572495

17. Jack CR, Wiste D, Vemuri P. Brain Beta- Amyloid Measures and Magnetic Resonance Imaging Atrophy Both Predict Timeto-Progression from Mild Cognitive Impairment to Alzheimer's Disease. Brain 2010,133, 3336-3348. doi: 10.1093/brain/ awq277.

18. Meena, A. A Study of Functional Brain Metabolism Using PET Scan Image Datasets: An Analysis. J.Comput. 2013, 6, 28-30.

19. Miners JS, Barua N, Kehoe PG, Gill S, Seth L. A $\beta$-Degrading Enzymes: Potential for Treatment of Alzheimer Disease. Journal of Neuropathology \& Experimental Neurology, Volume 70, Issue 11, November 2011, Pages 944-959, https://doi.org/10.1097/ NEN.0b013e3182345e46.

20. Witter S, Witter R, Vilu R, Samosona A. Medical Plants and Nutraceuticals for Amyloid- $\beta$ Fibrillation Inhibition. J Alzheimers Dis Rep. 2018; 2(1): 239-252. doi: 10.3233/ADR-180066
21. Rammohan V R, Descamps O, John V, Dale EB. Ayurvedic medicinal plants for Alzheimer's disease: a review. Alzheimer's Res Ther. 2012; 4(3): 22.doi: 10.1186/alzrt125

22. Yang F, Lim GP, Begum AN, Ubeda OJ, Simmons MR, Ambegaokar SS, Chen PP, Kayed R, Glabe CG, Frautschy SA, Cole GM. Curcumin inhibits the formation of amyloid-beta oligomers and fibrils, binds plaques, and reduces amyloid in vivo. J Biol Chem. 2005;280:5892-5901. DOI: 10.1074/jbc.M404751200

23. Lim GP, Chu T, Yang F, Beech W, Frautschy SA, Cole GM. The curry spice curcumin reduces oxidative damage and amyloid pathology in an Alzheimer transgenic mouse. J Neurosci. 2001;21:8370-8377. doi: 10.1523/JNEUROSCI.21-21-08370.2001

24. Shinomol GK, Bharath MM. Exploring the role of 'Brahmi' (Bocopa monnieri and Centella asiatica) in brain function and therapy. Recent Pat Endocr Metab Immune Drug Discov. 2011;5:33-49. doi: 10.2174/187221411794351833.

25. Singh RH, Narsimhamurthy K, Singh G. Neuronutrient impact of Ayurvedic Rasayana therapy in brain aging. Biogerontology. 2008;9:369-374. doi: 10.1007/s10522-008-9185-z.

26. Bhattacharya SK, Bhattacharya A, Kumar A, Ghosal S. Antioxidant activity of Bacopa monniera in rat frontal cortex, striatum and hippocampus. Phytother Res. 2000; 14:174-179. doi: $\quad 10.1002 /($ SICI)1099-1573(200005)14:3<174:AIDPTR624>3.0.CO;2-O.

27. Limpeanchob N, Jaipan S, Rattanakaruna S, Phrompittayarat W, Ingkaninan K. Neuroprotective effect of Bacopa monnieri on beta-amyloid-induced cell death in primary cortical culture. J Ethnopharmacol. 2008;120:112-117. doi: 10.1016/j. jep.2008.07.039.

28. Cervenka F, Jahodar L. Plant metabolites as nootropics and $\operatorname{cog}$ nitive. Ceska Slov Farm. 2006;55:219-229. Article in Czech.

29. Dhanasekaran M, Holcomb LA, Hitt AR, Tharakan B, Porter JW, Young KA, Manyam BV. Centella Asiatica extract selectively decreases amyloid-beta levels in the hippocampus of the Alzheimer's disease animal model. Phytother Res. 2009;23:14 19. doi: $10.1002 /$ ptr. 2405 .

30. Veerendra Kumar MH, Gupta YK. Effect of Centella Asiatica on cognition and oxidative stress in an intracerebroventricular streptozotocin model of Alzheimer's disease in rats. Clin Exp Pharmacol Physiol. 2003;30:336-342. doi: 10.1046/j.14401681.2003.03842.x.

31. Malik J, Karan M, Vasisht K. Nootropic, anxiolytic and CNS-depressant studies on different plant sources of shankhpushpi. Pharm Biol. 2011;49:1234-1242. doi: 10.3109/13880209.2011.584539.

32. Mukherjee PK, Kumar V, Kumar NS, Heinrich M. The Ayurvedic medicine Clitoria ternatea--from traditional use to scientific assessment. J Ethnopharmacol. 2008;120:291-301. doi: 10.1016/j.jep.2008.09.009.

33. Hao W, Friedman A. Mathematical model on Alzheimer's disease. BMC Syst Biol. 2016:10(1):108. doi: 10.1186/s12918016-0348-2.

34. Puri KI, Li L. Mathematical Modeling for the Pathogenesis of Alzheimer's Disease. PLoS ONE 5(12): e15176. https://doi. org/10.1371/journal.pone.0015176

35. Voropaeva OV, Bayadilov OV, Leontiev SV. Mathematical modelling of the dynamics of cell death in aseptic inflammation, in Actual Problems of Applied Mathematics, Computer Science and Mechanics, International Scientific and Technical Conference Proceedings 2017. pp. 625-631.

36. Daina A, Michielin O, Zoete V. SwissADME: a free web tool to evaluate pharmacokinetics, drug-likeness and medicinal chemistry friendliness of small molecules. Sci Rep. 2017:7:42717. doi: $10.1038 /$ srep42717. 